\title{
The Implementation of Simulation Method in Training Program for Improving Biologi Teacher Skills in Using Local Environment as Learning Resources
}

\author{
Agus Asep Sulaeman ${ }^{*}$ \\ Widyaiswara Pusat Pengembangan dan Pemberdayaan Pendidik dan Tenaga Kependidikan IPA \\ Corresponding Author. Email: Agusp3g@yahoo.com
}

Keywords:
simulation
methods,
teacher's ability,
outdoor
environment.

\section{INRODUCTION}

The purposes of biology learning in schools are to generate and strengthen students' spiritual attitudes and social attitudes, provide their knowledge, and equip them with relevant skills, so they are able to solve the problems in daily life as a citizen (Kemdikbud, 2014). Through appropriate biological learning processes, students can grow their awareness of the complexity of biodiversity and bioprocess, and the application of biology, as well as the sensitivity and awarness to environmental issues, take care of the environment as manifestation of their spiritual attitudes (Khatoon et al., 2014 ; Kemdikbud, 2014). In addition, students can be more aware that the science and technology they are learning is beneficial to individuals, communities, and the environment, and understand that environmental conservation aims for the well-being of society as well (Braund \& Reis, 2006; Cimer, 2012; Badri, et al., 2016)

In order to achieve these learning objectives, biology teachers can use the environment (outdor) as a learning resource (Brund \& Reis, 2006; Badri, et al., 2016). Using outdor as learning resource is one of the contextual learning strategies. As stated Stanisavljević et al., (2016) which states that contextual learning is defined as learning that uses concepts and process skills that are relevant to students in the real life context of the students. This outdor learning can involve learning from the various informal learning sources that occur in the home everyday; interacting with friends, watching $\mathrm{TV}$, reading books or magazines; in various community meetings with the same hobbies, youth and social media interactions; and study at institutions, such as museums and zoos (Badri et al., 2016). 
Based on the results of the analysis there are some benefits of outdor learning, among which 1) can generate student ideas in applying the content being studied (Balschweid, 2002; Cimer, 2012); 2) can develop logical thinking and reasoning in looking at environmental issues of daily life (Carier, et al., 2014); 3) create a strong emotional experience for their students learn not only by remembering; (Balschweid, 2002) and 4) develop environmental awareness (Bogmer \& Wiseman, 2004); and 5) increase student interest in learning science (Badri, et al., 2016). Conversely, if less learning provides experience in an open environment, students experience a loss in learning the ecological concept - the constent that bridges between biology and the environment (Eick, 2012). One of the main strategies for building environmental education is learning in outdor, as it contributes to students to practice analyzing environmental problems.

Dilon, et al., (2006) stated that they found important evidence indicating that learning in an out-of-class environment, properly arranged, properly planned, well taught, and followed effectively, can provide students with opportunities to develop knowledge and his skills. That statement is supported by many experts, the learning of science from outside the school that is integrated into the authentic curriculum, will more involve and improve students' positive orientation to science, so that learning is more meaningful and useful (Warnick, et al., 2004; Stephenson, et al., 2008 ; Yager, et al., 2012). These conditions occur because students get value-added knowledge based on their daily experiences (Braund \& Reiss, 2006).

However, current biology learning in schools is isolated from the problems of everyday life (Stanisavljević, et al., 2016). Science experiences gained by students at home and in other informal sectors are often very different from those given in school (Braund \& Reis, 2006). In fact, students spend about two-thirds of their lives outside formal schooling, educators tend to ignore the insights and attitudes that students experience outside of school. The result, so far students see very little relationship between biology and their daily life (Cimer, 2012). Students often see science as knowledge belonging to class. As a result, the learners fail to develop an in-depth understanding of science and mathematics in a traditional classroom, so they fail to apply science knowledge in their life - outside the classroom (Balschweid, 2002). This condition is one of the reasons for biology learning is not interesting and considered difficult by students (Brund \& Reis, 2006; Stanisavljević, et al., 2016). In addition, learning what happened today just transferring knowledge to students, and still centered on the teacher. This leads to not getting the experience to understand the concept in full by the student (Sukardiyono \& Rosana, 2017).

The problem faced in integrating out-ofclass issues into an authentic curriculum is the lack of teacher expertise in designing learning, so that they can not develop teaching schemes that are appropriate to student life (Liu, et al., 2009). Should it happen, students usually just do a quick, casual observation outdoors, which may not produce enough or valuable knowledge. Badri, et al., (2016) notes that the condition occurs because there are still many teachers lack the training to be able to teach physics, biology, and chemistry interdisciplinary. Therefore, the need for today's professional programs is to make teachers more adept in teaching biology in an interdisciplinary way, integrating science with contextual, both at preservice and inservice levels (Marshall, 2010; Cimer, 2012; Siew, 2013), including supporting students developing a more positive self-biological self-concept gained from outside school experience (Badri, et al., 2016).

In order to overcome these problems, the center for the development and empowerment of educators and natural science education personnel (PPPPTK IPA) develops the program for improving biologi teacher skills in using local environment as learning resources using simulation methods. The use of this method is expected to provide knowledge and skills to identify external environmental conditions to biology teachers, and then to integrate them into biological learning in the form of guidebooks. In this case, the teachers directly apply of the development procedure (Coffman, 2012), begin from planning, observing the environment, developing learning scenarios, student activity sheets, and making the assessment instrument, for resulting in a complete learning guide document.

Therefore, to know the success of the training program implementation objectives of this study are: 1) the ability of teachers to use the environment as a source of learning; 2) knowing mastery of teacher concept during training; and 3) teacher response to training implementation.

\section{METHODS}

The training was conducted through 6 days $(50$ JP) with 36 participants consisting of representative biology teachers from regencies / cities in Special Province of Yogyakarta, Central Java, and East Java which was held on 11 s.d. April 15, 2016. The activity was facilitated by two science instructors from PPPPTK IPA. The 
material presented consist of: 1) Education for Sustainable Development; 2) Environmental Ethics; 3) Learning Resources and Their Use in Learning; 4) Analysis of Phenomena and Coastal Environment Issues; 5) Preparation of Learning Devices; and 6) Preparation of innovative work reports in the form of learning guides.

The training process uses simulation method, that is, the teacher jointly experiences the learning development stage, starting from planning, observing the environment in the mangrove forest, compiling the learning scenario, the student activity sheet, and the making of the assessment instrument, resulting in the document of learning guide in Mangrove Forest Wonorejo Surabaya. The learning process is done andragogi with concept approach, skill, and product. After completion of the training, participants practice the use of the environment as a learning resource in the form of learning guides in their respective areas. This instructional guide product is submitted to the facilitator in the last week of October 2016 via e-mail.

In order to know the success of the program, the data captured the ability of teachers to use the environment as a source of learning, concept pengusaan, and response to the training process. In order to know the skills of teachers in using the environment as a learning resource is done by assessing the instructional guides that have been prepared, with aspects of the assessment consisting of: 1) Themes, 2) Preliminary disclosure; 3) Learning content; 4) Learning Scenario; 5) Student Activity Sheet; 6) Assessment; and 7) Systematics. The concept of conceptual data is done through pretest and end test (postes) using thirty multiple choice questions with four alternative answer options. The data of participants' responses to the learning process were collected using questionnaires. The statement items developed in the questionnaire consist of: 1) Material Compliance with Needs; 2) The Role of Facilitator of Learning Implementation; 3) Learning Implementation Process; 4) Training Facilities; 5) Benefits of Training for Participants; and 6) Follow-Up of Training Results by Participants.

Data analysis of pretest and posttest result compared with using excel program and t-test with significance level $\alpha=5 \%$ to get data of increase of learning result as influence of treatment to conceptualization. Data analysis on the instructional guidance that was made and the teacher's response after following the training was done descriptively quantitative.

\section{RESULTS}

The results presented in this study consist of the ability of teachers to use the environment outside the classroom as a learning resource in the form of learning guides. conceptual mastery, and response to training implementation. Furthermore, a discussion of the results obtained during the study.

\section{Tecaher Skill in Using the Environment as a Learning Resource}

Score assessment of aspects of the ability of teachers in using the environment as a learning resource can be seen in Figure 1. Based on the picture shows that the teachers' skill achieve good criteria.

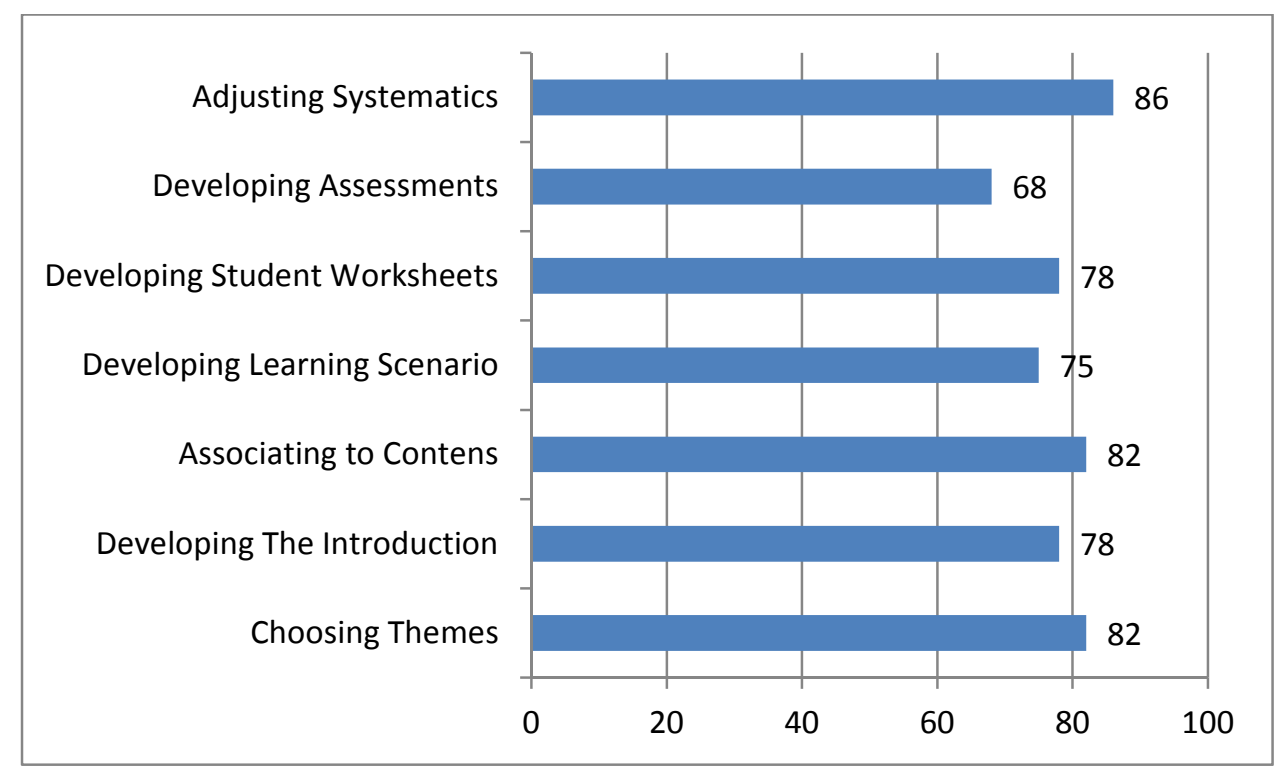

Figure 1. The Score of Teacher' Skills in Using Outdoor Environment as A Lerning Resource

Copyright @ $\odot 2018$, JSER, e-ISSN: 2597-9701 
Based on Figure 1. the score of every aspect of the teacher's ability to develop the use of the environment as a source of learning. The value of the aspect of compatibility with the format yields the highest value, that is 86 . The aspect that reaches the lowest value is to make an assessment, that is 68 .

Based on Figure 1. the score of every aspect of the teacher's ability to develop the use of the environment as a source of learning. The value of the aspect of compatibility with the format yields the highest value, that is 86 . The aspect that reaches the lowest value is to make an assessment, that is 68 .

\section{Mastery of concept}

Concept mastery data is captured through pretest and postes activities. The mean of pretest and postes is presented in the graph in Figure 2.Based on Figure 2, there is a noticeable increase in the concept mastery by the participants at the time before and after the training which indicates that the pretest grade is lower than postes. To know the difference of values between mastering the concept of students at the beginning and at the end, conducted statistical analysis of the data. The results of normality analysis, homogeneity, and different test can be seen in Table 1. Based on the results of the analysis, the initial test scores and the final test score of the concept of distributed normal and homogeneous. In order to know the significance of the difference between the pretest and postes concept mastery scores by the participants, the data were tested using a twoaveraging difference test.

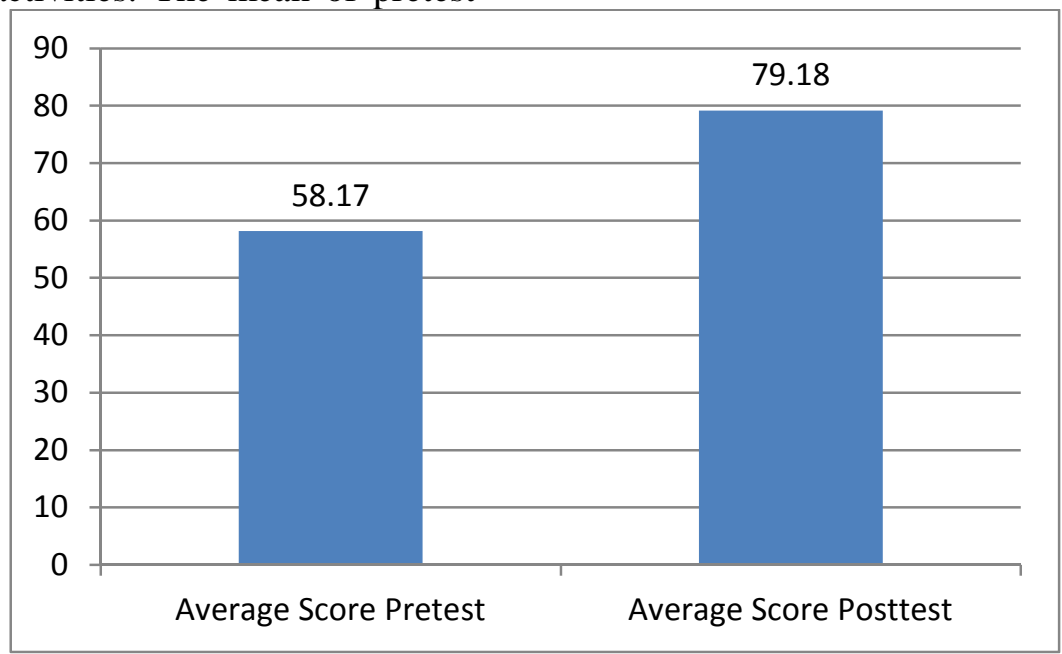

Figure 2. The Graph of Mean Pretest and Postest

Based on the data in Table 1. obtained tarithmetical scores of mastering the concept by the participants are on the t-critical area for $\alpha=0.05$ so it can be concluded that $\mathrm{HO}$ is rejected. That is, there is a significant difference between mastering the concept of participants at the beginning and at the end of learning. The condition indicates that the training mikan influence on the mastery of the concept by the participants.

Table 1. Statistical Analysis of Pretest and Posttest Average

\begin{tabular}{ccc}
\hline Statisticaly & \multicolumn{2}{c}{ Average of } \\
\cline { 2 - 3 } Parameter & Pretest & Postest \\
\hline $\mathrm{x}$ & 58,17 & 79,18 \\
$\mathrm{n}$ & 36 & 36 \\
$\mathrm{df}$ & 35 & 35 \\
Liliefors & 0,117 & 0,145 \\
Lilieforsyze & 0,165 & 0,165 \\
$\mathrm{~F}_{\text {analyze }}$ & \multicolumn{2}{c}{1,907} \\
$\mathrm{~F}_{\text {table }}$ & \multicolumn{2}{c}{1,955} \\
Uji-t & \multicolumn{2}{c}{0} \\
\hline
\end{tabular}




\section{Teacher's R esponse to Implementations' A spects of T raining Program}

The response of the participating teachers to the training program was obtained through a questionnaire of attitude scale. Based on the questionnaires that have been studied by the teachers of the training participants, it can be seen the response for each aspect as shown in Figure 3. Based on Figure 3., teh most teachers stated strongly agreed to all indicators of training implementation. They feel that the facilitators are delivered according to need and are very useful, so they find it helpful to make learning guides that use the outside environment as a learning resource. Based on the data, the response in following up get the smallest value. The condition is related to the motivation of the participants in developing the learning guide in their lives.

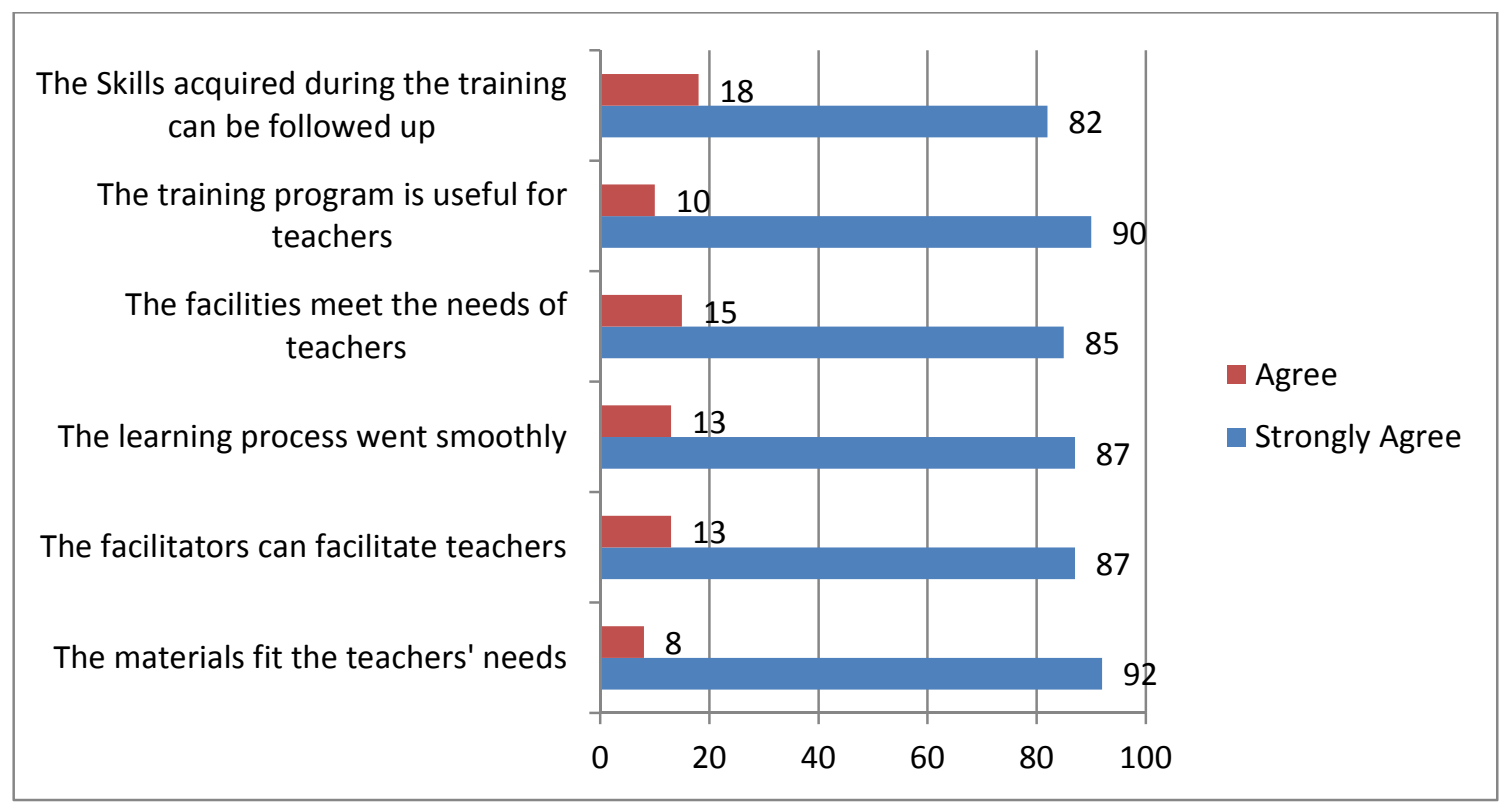

Figure 3. The teachers' responses to training aspects (\%)

\section{DISCUSSION}

Based on the results of the study shows that teachers have been able to implement their skills in using the environment in their respective areas as learning resources that are packaged in the form of learning guides. This condition can occur because they have been trained at the time of simulation. Teachers experience the immediate stages of activity in the preparation of contextual contextual learning guides during training. As Coffman (2012) points out, the simulation method in the learning process embodies a constructivist environment that can train participants to be able to assemble interrelated elements and information to solve real-world problems. Training using simulation methods provides more opportunities for participants to develop and train the required competencies, while receiving feedback (Salas et al., 2008). During the training, in addition to being given the knowledge and skills trained, the participants also get direct feedback, either from the facilitator or other participants. That is, the training process undertaken provides an opportunity for experienced teachers to share knowledge and skills with new members, so that they can improve their competence (Oztaukano, 2010).

This training did not automatically improve the ability of teachers in preparing a contextual assessment. Based on the results, the achivement of aspects of contextual assessment was low. This condition is related to techers' knowledge and skills in developing of contextual assessment is still lacking. Many studies suggest that many teachers have not been able to develop a contextual science assessment. Therefore, to improve aspects of techers' ability to prepare a contextual biological assessment required a separate training content. 
The training carried out has a good impact on the concept of training participants. There is a significant difference in value between the average pretest and postes. In addition, participants felt that the material delivered was in accordance with the needs of the participants. In the training process, participants will be motivated to learn the material well if the material is delivered according to their professional needs (Timperley, et al., 2007). This is also in line with the opinion of Gorozidis \& Papaioannou, 2014) which states that the relevance of training materials determines the willingness of teachers to learn (learning motivation). The motivation to learn in teacher training is one of the basic keys that determines the success of the professional development program penyeleanggaraan.

This condition occurs because through the simulation method the participants experience and are directly involved in every learning stage until they can make guidance on the use of the environment as a learning resource. As presented by Coffman (2012), the simulation method gives a very real experience, the learning process requires the involvement and active participation of the training participants. The simulation method encourages well the transfer of knowledge and helps to apply certain issues or concepts. This simulation method requires a process of active involvement of participants who can improve the mastery of knowledge, so as to increase academic value. As Cimer (2007) points out, when learners engage in practical work, they can test, rethink and reconstruct their ideas and thoughts to improve their understanding. Similarly, Panda research results (2014) show that the use of simulation methods at the student level has a positive impact, so that the prospective teachers become more competent pedagogically to teach science and show excellent content mastery. This method also motivates participants to goal-oriented, so it is very effective in improving learning achievement (Ganyaupfu, 2013).

Master responds very well to all aspects of the training. This condition indicates that the teacher understands the content, enjoys the learning process as an active participant, and is able to find solutions to problems in developing learning that use the outside environment as a source of learning. As is known, in the process of active learning, participants control their own behavior by making wise decisions for the learning process. Participants are positive about learning, which in turn makes them think that learning in the training they follow is for their own sake. It encourages them to actively explore, question, and understand the material and master their skills well during training (Keyong Lee \& Erdogan, 2007).

\section{CONCLUSIONS}

Through this training program, biology teachers gain knowledge on topics that directly relate to the development of learning guides using the outdoor environment as a source of learning. In the simulation learning process, teachers are trained in developing environmental guidance guides through very real experiences, from designing to forming a collaborative guide example. The results of the training program show that teachers can use the environment as a good source of learning, improve concept mastery, and feel happy to attanding the learning process. After teachers practice the skills trained in their respective school environments, documentation guidance of environmental uses is also provided as a contextual learning resource.

In general, the implementation of this training has shown good results, however, this training has not been able to improve the teacher's skill in preparing contextual biology assessment. Therefore, for the implementation of the next training, additional material is needed "Contextual Assessment" which is equipped with adequate teaching materials. A further assessment that can be done is to measure the success of the implementation of environmental use guidelines as a learning resource that teachers have created at the classroom level.

\section{REFERENCES}

A. Çimer. (2017). Effective teaching in science: A review of literature. Journal of Turkish Science Education, Vol. 4, Issue 1, pp. 2044.

A. Çimer. (2012). What makes biology learning difficult and effective: Students' views. Educational Research and Reviews, Vol. 7, No. 3, pp. 61-71.

B. K. Warnick, G. W. Thompson, \& E. S. Gummer. Perceptions of science teachers regarding the integration of science into the agriculture education curriculum. Journal of Agricultural Education, Vol. 45, No. 1, pp. 62-73, 2004.

C. J. Eick. (2012). Use of the outdoor classroom and nature-study to support science and literacy learning: A narrative case study of a third-grade classroom. Journal Science Teacher Education, Vol 23, Issue 7, pp. 789803. 
E. M. Ganyaupfu, E. M. (2013). Teaching methods and students' academic performance. International Journal of Humanities and Social Science Invention, Vol. 2, Issue 9, pp. 29-35.

E. Salas, K. A. Wilson, E. H. Lazzara, H. B. King, J. S. Augenstein, D. W. Robinson, \& D. J. Bimbach. (2008). Simulation-based training for patient safety: 10 principles that matter," Journal Patient Safety, Vol. 8, Issue 1, pp. 3-8.

G. Gorozidis \& A, G. Papaioannou. Teachers' motivation to participate in training and to implement innovations. Teaching and Teacher Education, Vol. 39, pp. 1-11, Apr. 2014.

G. Marshal, Student centered. (2010). Active learning pedagogies in chemistry education. Making Chemistry Relevant, Sharsmistha, $B$. (ed.). New Jersey : A John Wiley \& Sons, Inc.

H. Timperley, A. Wilson, H. Barrar, \& I. Fung, I. (2007). Teacher Professional Learning and Development; Best Evidence Synthesis University of Auckland Iteration [BES]. New Zealand. New Zealand Ministry of Education.

J. D., Stanisavljevic, M. G. Pejcic, \& L. Z. Stanisavljevic. (2016). The application of context-based teaching in the realization of the program content "the decline of pollinators. Journal of Subject Didactics, Vol. 1, No. 1, pp. 51-63.

J. Dillon, M. Rickinson, K Teamey, M. Morris, M. Y. Choi, D. Sanders, \& P. Benefield. (2006). The value of outdoor learning: evidence from research in the UK and elsewhere. School Science Review, Vol 87, No. 320, pp. 107-111.

Kementerian Pendidikan dan Kebudayaan. (2014). Peraturan Menteri Pendidikan dan Kebudayaan Republik Indonesia Nomor 59 Tahun 2014 Tentang Kurikulum 2013 Sekolah Menengah Atas/Madrasah Aliyah. Jakarta; Kemdikbud

Kyeong Lee, M. \& Erdogan, I. (2007). The effect of science-technology-society teaching on students' attitudes toward science and certain aspects of creativity. International Journal of Science Education, 29 (11), hlm. 1315- 1327.

L. G. Stephenson, B. K. Warnick, \& R. S. Tarpley. (2008). Collaboration between science and agriculture teacher. Journal of Agricultural Education, Vol. 49, No. 4, pp. 106-119.

M. Balschweid. (2002). Teaching biology using agriculture as the context: Perceptions of high school students. Journal of Agricultural Education, Vol. 43, No 2, pp. 56-67.

M. Braund, \& M. Reiss. (2006). Toward a more authentic science curiculum: The contribution of out-of-school learning. International Journal of Science Education. Vol 28, No 12, pp. 1373-1388.

M. Badri, G. Yang, K. Al Mazroui, J. Mohaidat,, A. Al Rashedi, N. \& Al Housani (2016). Out-of-school experience categories influencing interest in biology of secondary school students by gender: exploration on an Abu Dhabi sample. Journal of Biological Education, Vol. 51, No. 2, pp. 166-185.

N. M. Siew, 'Exploring primary science teachers' creativity and attitudes through responses to creative questions in university physics lessons," British Journal of Education, Society \& Behavioural Science, Vol 3, Issue 1, pp. 93-108, Mar 2013

O. B. Oztaukano. (2010). Identifying the in-service training needs of the social studies teachers within the context of lifelong learning. Procedia Social and Behavioral Sciences, Vol. 2, Issue 2, pp. 3036-3042.

S. J. Carrier, M. M. Thomson, L. P. Tugurian. \& K. T. Stevenson. (2014). Elementary science education in classrooms and outdoors: stakeholder views, gender, ethnicity, and testing. International Journal of Science Education, Vol. 36, Issue 13, pp. 2195-2220.

S. O. Yager, O. K. Dogan, E. Haceeminoglu, \& R. E. Yager. (2012). The role of student and teacher creativity in aiding current reform efforts in science and technology education. National Forum of Alied Educational Research Journal, Vol. 25, No. 3, pp. 1-22.

S. Panda. (2014). Enriching pedagogical competency of science teachers through simulation class in pre-service teacher education: an action research in college of teacher education. IOSR Journal of Research \& Method in Education, Vol. 4, Issue 2, pp. 25-29.

Sukardiyono \& Dadan Rosana. (2017). Implementation of Integrated Science Instruction Assessment as An Alternative to Measure Science Process Skills And Social Attitudes. Journal of Science Education Research Vol 1, No 1.

T. Coffman. (2012). Using simulations to enhance teaching and learning: Encouraging the creative process. VSTE Journal, Vol. 21, No. 2, pp. 1-7.

T. Y. Liu, T. H. Tan, \& Y. L. Chu. (2009). Outdoor natural science learning with an RFID-supported immersive ubiquitous 
Asep Agus Sulaeman / JSER 2018, 2(1), 8

learning environment. Educational Technology \& Society, Vol. 12, No. 4, pp. 161- 175.

Z. Khatoon, M. T. Alam, M. A. Bukhari, \& M. Mushtaq. (2014). In-service teachers' perception about their competencies in delivery of biology lessons. International Journal of Asian Social Science. Vol. 4, Issue 7 ,

pp.

820-834 